\title{
INVESTIGATION IN ORDER TO DEFINED THE TECHNOLOGICAL PROCESS OF OBTAINING FILLERS FOR USE IN VARIOUS INDUSTRIES ON THE BASIS OF LIMESTONE “GIGOVIĆI”-ULCINJ
}

\author{
Dragan S. Radulović ${ }^{1, \#, ~ M i l a n ~ P e t r o v ~}{ }^{1}$, Grozdanka Bogdanović \\ Ljubiša Andrić ${ }^{1}$, Darko Božović ${ }^{3}$ \\ ${ }^{1}$ Institute for technology of nuclear and other mineral raw materials, \\ 86 Franchet d'Espery Street, Belgrade, Serbia \\ ${ }^{2}$ University of Belgrade, Techical faculty in Bor, Vojske Jugoslavije 12, Bor, Serbia \\ ${ }^{3}$ Geological Survey, Podgorica, Montenegro
}

(Received: November 1, 2017; Accepted: December 15, 2017)

\begin{abstract}
This paper presents results of investigations of the possibility of using "Gigovići”-Ulcinj limestone (Republic Montenegro) as filler in various industry branches. Micronization methods, granulometric composition, oil and water absorption and degree of whiteness were investigated, and chemical and thermal analyses (DT/TG) were performed.

Physico-chemical properties of this limestone classify it among high quality carbonate raw materials with relatively high $\mathrm{CaCO}_{3}$ content of $98.16 \%$, as well as low $\mathrm{MgCO}_{3}$ content of $1.53 \%$ and low silicate content $\left(\mathrm{SiO}_{2}\right.$ $0.30 \%)$. Its quality satisfies requirements of standards on using of calcium carbonate as filler in industry of paints and coatings; paper industry, rubber and PVC industry; glass industry; production of mineral fertilizers; foundry industry; sugar industry and metallurgy. Due to the low degree of whiteness (85.25\%) "Gigovići" limestone cannot be used in pharmaceutical and cosmetics industry. Due to relatively high content of $\mathrm{MgO}(0.73 \%)$ and $\mathrm{Fe}(340 \mathrm{ppm})$, as well as high content of heavy metals, $\mathrm{Cu}$ (18 ppm), Ni (24 ppm) and Cd (9 ppm), "Gigovici i" limestone cannot be used, in production of cattle feed and for neutralization of acidic soils.
\end{abstract}

Key words: limestone; filler; industrial use; standards; comminution; classification.

\section{Introduction}

The limestone is a sedimentary rock predominantly comprising of carbonate minerals (i.e., calcium carbonate, $\mathrm{CaCO}_{3}$ ) in the quantity that surpasses $50 \%$. Quartz and clay minerals (e.g. kaolinite, hydrous mica, montmorillonite) are other two major limestone constituents $\left[\begin{array}{ll}1, & 2] \text {. Since a }\end{array}\right.$ substitution of calcium by magnesium occasionally occurs, a limestone that contains $5-35 \%$ of $\mathrm{Mg}$ is defined as "magnesian limestone". If $\mathrm{Mg}$ content is below $5 \%$, the rock is classified as a "high-calcium limestone" $[2,3]$. The carbonates present in the limestone customarily appear as calcite, aragonite and/or vaterite mineral phases. However, the only crystal form of real significance is calcite $[2,4]$.

Calcite $\left(\mathrm{CaCO}_{3}\right)$ is one of the most common minerals on Earth, comprising about 4\% mass of the Earth's crust [5]. Calcite occurs in carbonates and nepheline syenites as the primary component of the magmatic phase, and it is also quite common in hydrothermal deposits. In metamorphosed

\#Corresponding author: d.radulovic@itnms.ac.rs

*A part of this study was presented at the XII International Symposium on Recycling Technologies and Sustainable Development (XII RTSD), organized by University of Belgrade, Technical faculty in Bor, from $13^{\text {th }}$ to $15^{\text {th }}$ September 2017, Hotel Jezero, Bor Lake, Serbia. 
deposits, calcite occurs in form of marble. In carbonates, dolomite $(\mathrm{Ca}, \mathrm{Mg}) \mathrm{CO}_{3}$, magnesite $\left(\mathrm{MgCO}_{3}\right)$, siderite $\left(\mathrm{FeCO}_{3}\right)$, rhodochrosite $\left(\mathrm{MnCO}_{3}\right)$ and smithsonite $\left(\mathrm{ZnCO}_{3}\right)$ occur as isomorphous with calcite [6].

By being the most abundant, and enclosing at least $50 \%$ of all present mineral phases in the limestone, calcite is an important resource and subject of investigations in various scientific fields: mineralogy, chemistry, physics, materials science [2, 7-10]. Calcite crystallizes rhombohedrally, in a hexagonal-

scalenohedral class and space group $R \overline{3} c$. The parameters of a single cell are as follows: $a=b=4.988 \AA, c=17.061 \AA, \alpha=\beta=90^{\circ}$, $\gamma=120^{\circ}, V=367.85 \AA^{3}, Z=6$ [11- 15]. Due to the perfect rhombohedral cleavage, calcite exhibits a small value of Mohs hardness (3.0). The specific gravity of calcite is 2.7 [4]. The thermally induced behavior, i.e. calcium carbonate stability constrains and the rules of phase transitions, represents a basis for a comprehensive study of the limestone [16-18].

Calcite is used for production of lime and Portland cement, while in construction industry it is applied as crushed or decorative stone. Calcium is also an important micronutrient. Several commercial drugs (antacids and calcium supplements) are, in fact, ground limestone [19]. Limestone is also important as a filler in various branches of industry (pharmaceutical, fodder, PVC and rubber, paints and glue industries, mineral fertilizers industry, foundry, metallurgy, etc.), as well as in agriculture where it is used for adjustment of soil $\mathrm{pH}$ value.

Republic of Montenegro has big reserves of limestone in coastal area and in south of the territory [20]. Even though deposits are huge, limestone is mainly used in construction as construction stone, and to some extent as architectural stone [21]. Since calcium carbonate as filler is much more expensive than construction stone, relevant institutions in Montenegro initiated investigations of the possibility of using limestone as filler [22]. On the basis of the results obtained, it was evaluated whether it can be used as filler in accordance with standards (SRPS) in various industry branches [22- 27].

"Gigovići"-Ulcinj deposit consists of carbonate sediments, mostly limestone ones, and less dolomitic sediments. Ore reserves are estimated at about 5,000,000 t of limestone [20]. The aim of investigations presented in this paper is to determine the possibility of using raw material as filler in various industry branches.

\section{Experimental}

\subsection{Materials and methods}

Starting limestone sample used in investigations was from "Gigovići" - Ulcinj deposit. First, its specific volumetric weight (density) and granulometric composition were determined. Its density was measured by pycnometer with xylol as fluid, granulometric composition was determined by Tyler screen [28]. Granulometric composition of the micronized sample was determined by sieve size $63 \mu \mathrm{m}$, classification on Cyclosizer and Bach elutriator. Limestone filler quality was determined by chemical, mineralogical (XRD), DT/TG and FTIR spectroscopy analysis. Degree of whiteness was determined by whiteness meter, according to $\mathrm{MgO} 100 \%$ standard.

Mineralogical analysis of the limestone samples was conducted by means of the X-ray powder diffraction (XRD) technique. The $\mathrm{X}$ ray powder diffraction patterns were acquired on a Philips PW-1710 automated diffractometer using a $\mathrm{Cu}$ tube operated at 40 $\mathrm{kV}$ and $30 \mathrm{~mA}$. The instrument was provided with a diffracted beam curved graphite monochromator and a Xe-filled proportional counter. Measurements were conducted at ambient temperature $\left(25^{\circ} \mathrm{C}\right)$. The diffraction 
data were assembled in the $2 \theta$ Bragg angle range from 5 to $70^{\circ}$, counting for $1 \mathrm{~s}$ (qualitative identification) at every $0.02^{\circ}$ step. The divergence and receiving slits were fixed at 1 and 0.1 , respectively.

The thermal behavior was monitored by simultaneous Differential thermal analysis (DTA) and thermo-gravimetry (TG) in the temperature range from $20^{\circ} \mathrm{C}$ to $1000^{\circ} \mathrm{C}$. DTA/TG analyses were conveyed in a static air flow by an automatic thermo-analyzing system: STA 409EP (Netzsch, Germany). The limestone samples (100 mg) were loosely packed into an alumina holder and thermally treated under a nitrogen atmosphere at a heating rate of $10^{\circ} \mathrm{C} / \mathrm{min}$, in temperature interval from 20 to $1000{ }^{\circ} \mathrm{C}$.

The chemical bonds, distinctive molecular fingerprints, functional groups and covalent bonding information were detected via Fourier Transform Infrared (FTIR) spectroscopy analysis. The FTIR spectra were obtained on a Nicolet IS-50 spectrometer (Thermo Fisher Scientific, USA), recorded in
$\mathrm{KBr}$ transmission mode in the $4000-400 \mathrm{~cm}^{-1}$ range and 32 scans at resolution 4.

The morphology of the samples was characterized by scanning electron microscopy (JEOL JSM-6610LV). The investigated samples were covered by gold using a sputter machine type BALTEC-SCD005 for improvement of the conductivity prior to imaging.

\subsection{Investigation of physical properties of starting sample}

Specific volumetric weight of the starting sample is $\gamma=2,708 \mathrm{~g} / \mathrm{cm}^{3}$.

Based on the results of screening test, a diagram of particle size distribution is drawn, shown in Figure 1, for samples of limestone "Gigovići".

Figure 1 shows the direct curve of particle size distribution and cumulative curves, as well as sample of outflow and flow limestone deposits "Gigovići"-Ulcinj.

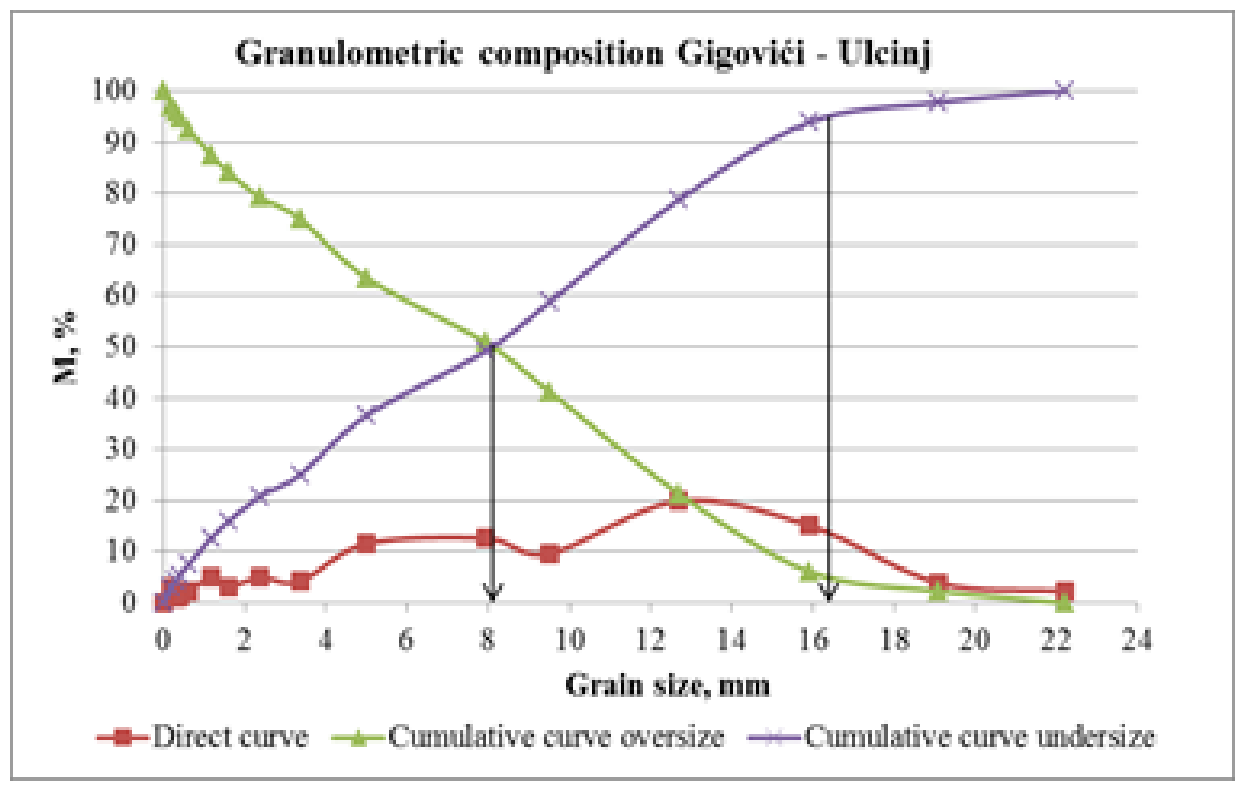

Figure 1. The curves of particle size- composition of the starting sample

"Gigovići"-Ulcinj, Montenegro 
From the intersection of cumulative curves, the average outflow and flow determined that the average diameter of the sample of limestone is d50 $=8.11 \mathrm{~mm}$, and the upper size limit of the sample is $\mathrm{d} 95=16.334 \mathrm{~mm}$.

\subsection{Technological investigations}

For investigations of the possibility of using limestone as filler in various industry branches, limestone was micronized, and the obtained products were subjected to the following physico-chemical characterization: chemical analysis, mineralogical analysis (XRD), thermal (DT/TG) analysis, Fourier Transform Infrared (FTIR) spectroscopy analysis, morphology of the samples by scanning electron microscopy (SEM), determination of granulometric composition, degree of whiteness and absorption of oil and water.

\subsubsection{Determining the granulometric composition of micronized sample}

Granulometric composition of the micronized products showed that the finest class $-5.7 \mu \mathrm{m}$ content is around $10 \%$.

Table 1. Granulometric composition of grinded sample "Gigovići"

\begin{tabular}{|c|c|c|c|}
\hline Size class $[\mu \mathrm{m}]$ & $\mathrm{M}, \%$ & $\downarrow \sum \mathrm{M}, \%$ & $\uparrow \sum \mathrm{M}, \%$ \\
\hline+63 & 38.24 & 38.24 & 100.00 \\
\hline$-63+44$ & 5.17 & 43.41 & 61.76 \\
\hline$-44+33$ & 5.61 & 49.02 & 56.59 \\
\hline$-33+23$ & 4.99 & 54.01 & 50.98 \\
\hline$-23+15$ & 3.63 & 57.64 & 45.99 \\
\hline$-15+11$ & 3.51 & 61.15 & 42.36 \\
\hline$-11+5,7$ & 28.86 & 90.01 & 38.85 \\
\hline$-5,7+0$ & 9.99 & 100.00 & 9.99 \\
\hline Input & 100.00 & $/$ & $/$ \\
\hline
\end{tabular}

\subsubsection{Chemical analysis}

Results of chemical analysis of the micronized limestone with contents of main components and damaging components are presented in Tables 2 and 3.
Results of physico-chemical characterization of "Gigovići" limestone sample and the required filler quality (Standards) lead to conclusion that this limestone is of good quality.

Table 2. Chemical composition of main components of limestone sample

\begin{tabular}{|c|c|c|c|c|c|c|c|c|c|c|c|c|}
\hline Comp. & $\mathrm{CaO}$ & $\mathrm{CaCO}_{3}$ & $\mathrm{CO}_{2}$ & $\mathrm{MgCO}_{3}$ & $\mathrm{Fe}_{2} \mathrm{O}_{3}$ & $\mathrm{Al}_{2} \mathrm{O}_{3}$ & $\mathrm{SiO}_{2}$ & $\mathrm{~K}_{2} \mathrm{O}$ & $\mathrm{Na}_{2} \mathrm{O}$ & $\mathrm{TiO}_{2}$ & $\mathrm{P}_{2} \mathrm{O}_{5}$ & $\mathrm{LOI}$ \\
\hline Cont., \% & 55,00 & 98,16 & 43,55 & 0,730 & 0,055 & 0,023 & 0,30 & 0,0064 & 0,022 & $<0,02$ & $<0,005$ & 43,80 \\
\hline
\end{tabular}

Table 3. Chemical composition of damaging components of limestone sample

\begin{tabular}{|c|c|c|c|c|c|c|c|c|c|c|c|c|c|c|}
\hline Comp. & $\mathrm{Cu}$ & $\mathrm{Mn}$ & $\mathrm{S}$ & $\mathrm{P}$ & $\mathrm{Ni}$ & $\mathrm{Cr}$ & $\mathrm{Mo}$ & $\mathrm{Sb}$ & $\mathrm{Pb}$ & $\mathrm{Cd}$ & $\mathrm{pH}$ & $\mathrm{Fe}$ solu. & $\mathrm{As}$ & $\mathrm{Hg}$ \\
\hline Cont., $\%$ & $\begin{array}{c}18 \\
\mathrm{ppm}\end{array}$ & $\begin{array}{c}36 \\
\mathrm{ppm}\end{array}$ & $<0,01$ & $<0,025$ & $\begin{array}{c}24 \\
\mathrm{ppm}\end{array}$ & $\begin{array}{c}3 \\
\mathrm{ppm}\end{array}$ & $\begin{array}{c}<50 \\
\mathrm{ppm}\end{array}$ & $\begin{array}{c}<25 \\
\mathrm{ppm}\end{array}$ & $\begin{array}{c}65 \\
\mathrm{ppm}\end{array}$ & $\begin{array}{c}9 \\
\mathrm{ppm}\end{array}$ & 9,26 & 0,0340 & $/$ & $/$ \\
\hline
\end{tabular}


Namely, its $\mathrm{CaCO}_{3}$ content is high - $98.16 \%$, and $\mathrm{MgCO}_{3}(1.53 \%)$ and silicates $\left(\mathrm{SiO}_{2} \quad 0.3 \%\right)$ content is low. However, relatively high content of heavy metals was found, above all $\mathrm{Cu}$ (18 ppm), Ni (24 ppm) and $\mathrm{Cd}(9 \mathrm{ppm})$.

\subsubsection{Determining the mineralogical composition of micronized sample}

\subsubsection{X-ray diffraction studies}

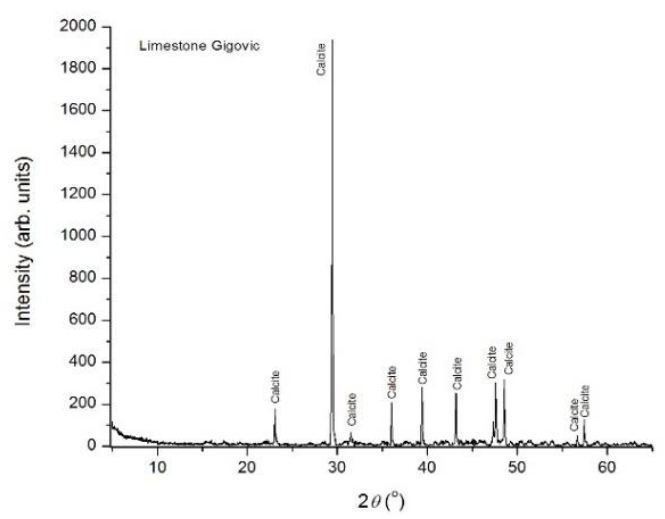

Figure 2. XRD diffractogram of "Gigović" limestone sample

The XRD diagram indicates that the investigated limestone sample is mainly composed of calcite with minor amounts of dolomite, quartz, mica, and clay minerals. The minor phases can scarcely be distinguished on the diagram, because their reflections are either too feeble or overlapped, and superposed by other more significant peaks. The calcite was found to be the most abundant in the investigated sample; therefore the most significant XRD reflections belong to this mineral phase.

According to the chemical analysis of the sample (Table 2), the content of calcium carbonate was $98.16 \%$. The intensity of the calcite XRD peaks (very high calcite peak of limestone situated at $30^{\circ}$ ) indicate a high level of crystallinity and presence of less amorphous solid.

\subsubsection{Infrared (FTIR) spectroscopy} analysis

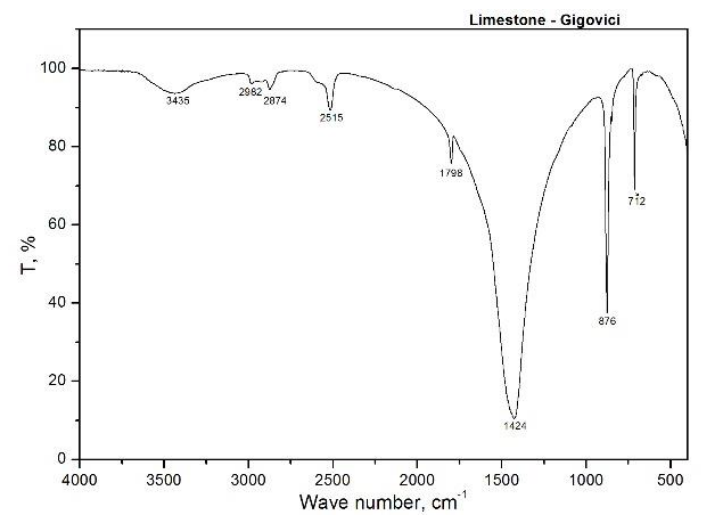

Figure 3. FTIR spectra of the "Gigović" limestone sample

The FTIR measurements were conducted in the wide region of $4000-400 \mathrm{~cm}^{-1}$. The free carbonate ion belongs to the symmetry point group $\mathrm{D}_{3 \mathrm{~h}}$. Therefore, the $\mathrm{CO}_{3}{ }^{2-}$ ion has four normal vibrations of which one belongs to the species $\mathrm{A}_{1}^{\prime}$, one is of species $\mathrm{A}_{2}^{\prime}$, while two vibrations belong to the E' species $[2,29]$. The carbonate functional group that is present in the calcite corresponds to the $\mathrm{D}_{3 \mathrm{~h}}$ point group as a nonlinear with 4 atoms $(\mathrm{N}=4)$. This group has $3 N-6=6$ basic vibrations of which $N-1=3$ are valent $[2,29]$. The spectral difference between the more common groups may be related to crystal structure. The spectral relationships among the minerals of several groups are not well known, due to the complicated composition and crystal structure. Infrared active groups of $\mathrm{CO}_{3}$, $\mathrm{HCO}_{3}, \mathrm{H}_{2} \mathrm{O}$ and $\mathrm{OH}$ normally dominate the absorption characteristics $[2,30]$.

In the FTIR spectrum of the calcium carbonates $\left(\mathrm{CaCO}_{3}\right)$, the main absorption bands appear in the regions $1500-1400 \mathrm{~cm}^{-1}$, $1100-1000 \mathrm{~cm}^{-1}, 900-800 \mathrm{~cm}^{-1}$ and close to $700 \mathrm{~cm}^{-1}$ [30]. The infrared spectra of the calcite and dolomite groups are normally characterized by three prominent absorption maxima and two minor peaks $[2,30]$. 
The analysis of the K19 sample showed eight peaks of different intensities on the diagram (given in Fig. 8): 3435, 2182, 2874 , $2515,1798,1424,876$ and $712 \mathrm{~cm}^{-1}$. The FTIR bands at 1424, 876 and $712 \mathrm{~cm}^{-1}$ had distinguished peaks, while the rest of peaks were minor. The registered bands are all considered to be caused by the $\mathrm{CO}_{3}$ groups with the crystals $[2,31]$. Namely, from the analysis of the space group characteristics, the existence of four molecular frequencies for the $\mathrm{CO}_{3}$ ions in calcite is acknowledged, of which three of them are active in the infrared spectrum [2, 30-32].

Since the $\mathrm{CaCO}_{3}$ contains less than one molecule of water per $\mathrm{CaCO}_{3}$ in the structure $[2,30]$, the bands that correspond to the three normal vibrations of the water molecule were found: at 3435, 2182, 2874 and $2515 \mathrm{~cm}^{-1}$ (antisymmetric and symmetric $\mathrm{O}-\mathrm{H}$ stretches), and at $1798 \mathrm{~cm}^{-1}$ (HOH bending). The band of medium intensity observed at $876 \mathrm{~cm}^{-1}$ is assigned to the $v_{2}$ which is a symmetric normal vibration of carbonate ion that corresponds to the $\mathrm{CO}_{3}$ out-of-plane deformation mode. The strong broad bond at $1424 \mathrm{~cm}^{-1}$ region corresponds to the symmetric normal $v_{3}$ vibration that is an asymmetric $\mathrm{C}-\mathrm{O}$ stretching mode. A relatively weak absorption at $700 \mathrm{~cm}^{-1}$ can be related to the $v_{4}$ vibration which is characterized by inplane deformation mode. As it can be seen in Fig. 6, the acknowledged bands are split, and the band maxima are being observed at 1424 , 876 and $712 \mathrm{~cm}^{-1}$. Thereby, the site symmetry for $\mathrm{CO}_{3}{ }^{2-}$ that is present in the limestone (i.e., calcite as the main phase) can be described as $\mathrm{D}_{3}\left(\mathrm{~A}_{1}(\mathrm{R})\left(v_{1}\right), \mathrm{A}_{2}(\mathrm{I})\left(v_{2}\right)\right.$ and $\left.\mathrm{E}(\mathrm{I}, \mathrm{R})\left(v_{3}, v_{4}\right)\right)$ which is in agreement with the crystalline structure that can be determined via XRD measurements $[2,30]$. Also, a frequency value of the infrared inactive fundamental $v_{1}$ of calcite can be determined from the frequencies of two combination bands $v_{1}+v_{3}$ and $v_{1}+v_{4}$ observed at $2515 \mathrm{~cm}^{-1}$ and
$1798 \mathrm{~cm}^{-1}$, respectively, for the samples at low temperature, resulting in the average value $1088 \mathrm{~cm}^{-1}$ for $v_{1}$, which is in agreement with the value that can be obtained from the Raman spectra of calcite [2,31].

\subsubsection{Scanning electron microscopic (SEM) analysis}

The sample Gigovići limestone, was submitted to the scanning electron microphotography to acquire finer observations of the sample's microstructure (Fig. 4).

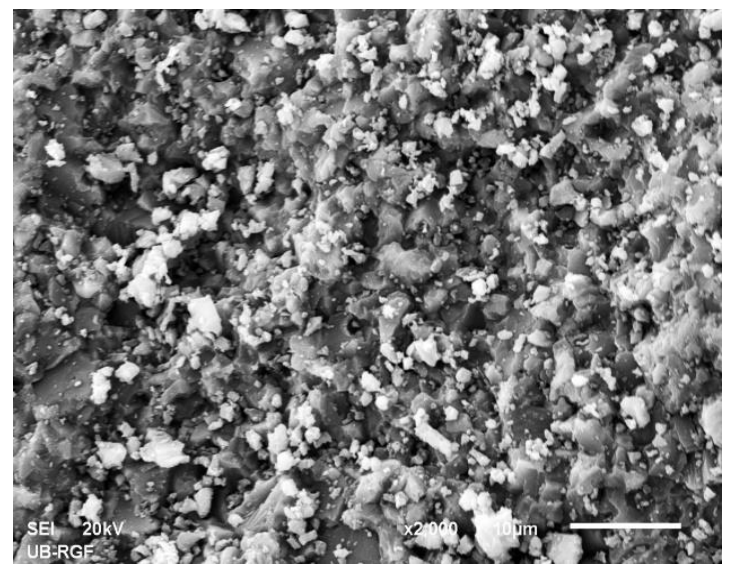

Figure 4. SEM microphotograph of the "Gigovići"-- limestone sample

\subsubsection{Determining the degree of whiteness}

Whiteness was assessed on three samples of the limestone from deposit "“Gigovići"", and the results are shown in Table 4.

Table 4. The degree of whiteness the limestone samples

\begin{tabular}{|c|c|c|}
\hline No & $\begin{array}{c}\text { mark of } \\
\text { the sample }\end{array}$ & $\begin{array}{c}\text { whiteness according } \\
\text { MgO- } 100 \%\end{array}$ \\
\hline 1. & "Gigovići"-1 & 85.30 \\
\hline 2 & "Gigovići"-2 & 85.10 \\
\hline 3 & "Gigovići"-3 & 85.35 \\
\hline & Average value & 85.25 \\
\hline
\end{tabular}




\subsubsection{Determination of absorption water and oil}

In order to determine the absorption of water and oil, three samples of the limestone from deposit "“Gigovići"”" are also used, and the results are shown in Tables 5 and 6 .

Table 5. Absorption of the oil of samples of limestone

\begin{tabular}{|c|c|c|}
\hline No. & $\begin{array}{c}\text { mark of } \\
\text { the sample }\end{array}$ & $\begin{array}{c}\text { absorption of } \\
\text { the oil, \% }\end{array}$ \\
\hline 1. & "Gigovići"-1 & 13.82 \\
\hline 2. & "Gigovići"-2 & 13.75 \\
\hline 3. & "Gigovići"-3 & 13.77 \\
\hline & Average value & 13.78 \\
\hline
\end{tabular}

Table 6. Absorption of the water of samples of limestone

\begin{tabular}{|c|c|c|}
\hline No & $\begin{array}{c}\text { mark of } \\
\text { the sample }\end{array}$ & $\begin{array}{c}\text { absorption of } \\
\text { the water, \% }\end{array}$ \\
\hline 1. & "Gigovići"-1 & 18.81 \\
\hline 2. & "Gigovići"-2 & 19.07 \\
\hline 3. & "Gigovići"-3 & 19.13 \\
\hline & Average value & 19.00 \\
\hline
\end{tabular}

\subsubsection{Thermal (DT/TG) analysis}

Thermo-analytical methods are commonly applied in investigations of mechanisms and kinetics of solid state decomposition reactions. The shape of a DTA and/or TG curve is a direct function of the kinetics of reaction that takes place within material, and it is also interrelated with chemical and mineralogical characteristics of the limestone [33]. The limestone thermal behavior was assessed by means of the analysis of thermogravimetric and differential thermal curves of the samples that originated from Gigovic deposits. The testing has been conducted under same controlled atmosphere (described in Chapter 2.)

Results of thermal (DTA/TG) analysis of the micronized sample "Gigovići" limestone are presented as a diagram in Figure 5.

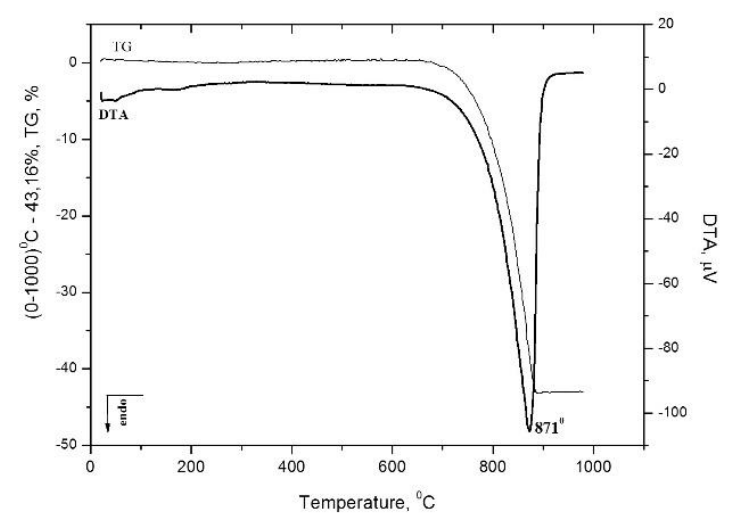

Figure 5. DTA/TG diagram of "Gigovići" limestone sample

The dominant thermally induced reaction that took place in the investigated limestone sample, which contained over $90 \%$ of calcium carbonate, is calcination, i.e., decomposition of $\mathrm{CaCO}_{3}$ induced by an exposure to strong heat. This reaction is important for the industrial application of limestone $[2,3,34]$.

The calcinations of the carbonate are an endothermic event, therefore a typical DTA curve for a sample of calcite rich limestone exhibits a single smooth decomposition step (Fig. 2). High-calcium limestone decomposes at temperatures in the vicinity of $800-900^{\circ} \mathrm{C}$ in one stage with the formation of calcium oxide and carbon dioxide. The dissociation proceeds gradually from the outside surface inwards, with the reaction taking place at an interface between calcite and the residual oxide $[2,3]$. The shape of the endothermic peak with calcination temperature maximum at $871^{\circ} \mathrm{C}$, is attributed to the decomposition of the calcite $\left(\mathrm{CaCO}_{3}\right)$ into $\mathrm{CaO}$ and $\mathrm{CO}_{2}$, according to the following reaction:

$$
\mathrm{CaCO}_{3} \rightarrow \mathrm{CaO}+\mathrm{CO}_{2}
$$

Immediately after this endothermic peak, DTA baseline does not drift neither endothermically nor exothermically, which means that there is no free lime present after 
the decomposition of calcite in the sample. The formation of the molten phase in the system did not appear in the applied thermal interval from $20^{\circ}$ up to $1000^{\circ} \mathrm{C}$.

The TGA curves of the limestone (Fig. 2) showing only one peak of the mass variation due to completed thermal decomposition (phase transformation) of the calcium carbonate. The major mass loss takes place at approximately $900^{\circ} \mathrm{C}$, and its value (measured in the temperature range from $650^{\circ} \mathrm{C}$ to $900^{\circ} \mathrm{C}$ ) are $43.16 \%$. The value of the mass loss is in consistency with the obtained LoI.

\section{Results and discussion}

Limestone filler quality for each industry branch is defined by appropriate standards or requirements of manufacturers who use limestone as raw material in their production cycle. Limestone quality requirements are defined as content of useful and damaging components, i.e., as chemical composition, as well as the necessary size class.

\subsection{Evaluation of "Gigovići" limestone filler quality based on chemical composition}

According to the results presented above, limestone from "Gigovići" - Ulcinj deposit can be used in the following industries:

- in the industry of paints and coatings; it is among high quality raw materials in accordance with market and standard requirements (SRPS B.B6.032);

- in paper industry; it is among A, B and $\mathrm{C}$ quality, while for the highest $\mathrm{D}$ quality its whiteness degree is not satisfying (SRPS B. B6.033);

- in rubber and PVC industry; it satisfies the highest quality standards and market requirements (SRPS B. B6.031);

- in foundry industry; it belongs to the highest class I in accordance with market requirements imposed by standard (SRPS B. B6.012);

- in sugar industry; due to the increased $\mathrm{MgO}$ content it belongs to the highest class in accordance with market and standard requirements (SRPS B. B6.013);

- in metallurgy; it is in the highest class I in accordance with market requirements imposed by standards (SRPS B.B6.011);

- in production of glass; due to the increased $\mathrm{MgO}, \mathrm{SiO}_{2}$ and $\mathrm{Fe}_{2} \mathrm{O}_{3}$ contents it is in quality category IV and $\mathrm{V}$ in accordance with market requirements imposed by standards (SRPS B. B6.020);

- for production of mineral fertilizers because of the increased $\mathrm{MgO}$ content, which is strictly defined by manufacturer's requirements (Azotara Pančevo).

Limestone from "Gigovići" - Ulcinj deposit cannot be used:

- in pharmaceutical and cosmetics industry because its low whiteness degree relative to market requirements defined by standard (SRPS B. B6.034);

- in production of cattle feed because of the increased content of heavy metals $\mathrm{Pb}$ and $\mathrm{Cd}$, which is very strictly defined for this use ("Official Gazette of the Republic of Serbia" 31/78, 6/81, 2/90, 20/00);

- for neutralization of acidic soils; because of the increased content of biogenic elements $\mathrm{MgO}, \mathrm{Fe}$ and $\mathrm{Cu}$, and heavy metals, $\mathrm{Pb}, \mathrm{Ni}$, and $\mathrm{Cd}$, the contents of which are very strictly defined ("Official Gazette of the Republic of Serbia” 60/2000).

\subsection{Evaluation of "Gigovići" - Ulcinj limestone filler quality based on users' requirements for the necessary raw material size (fineness)}

Some industries require finely micronized limestone, while others require raw material of larger particle size, sometimes even coarse. 
Following industries use ground and micronized limestone:

- for paints and coatings industry; A quality $99.5 \%$ of $-20 \mu \mathrm{m}$, B quality $97 \%$ of $-20 \mu \mathrm{m}$ and $0.01 \%$ of $+44 \mu \mathrm{m}$;

- for paper industry for all quality categories (A, B and C) the required fineness is $100 \%$ of $-45 \mu \mathrm{m}$, where for A quality $75 \%$ of $-10 \mu \mathrm{m}$, for B quality $80 \%$, and for $\mathrm{C}$ quality the required fineness is $95 \%$ of $-10 \mu \mathrm{m}$ and $90 \%$ of $-2 \mu \mathrm{m}$;

- rubber and PVC industry requires for $\mathrm{A}$ and B quality raw material to be $99.5 \%$ of $-45 \mu \mathrm{m}$, while for $\mathrm{C}$ and $\mathrm{D}$ quality upper limit limestone size is $45 \mu \mathrm{m}$;

- for glass industry, since "Gigovići" limestone corresponds to quality IV and $\mathrm{V}$ according to its chemical composition, there is predefined granulometric composition for these quality classes, subdivided into six subclasses in size range from $-1+0.1 \mathrm{~mm}$;

Following industries demand larger sizes and coarse limestone:

- for foundry industry, raw material should be size $-50+30 \mathrm{~mm}$, with class $-30 \mathrm{~mm}$ content up to $5 \%<$;

- for sugar industry, limestone is to be classified into six subclasses in size range from $-215+63 \mathrm{~mm}$, with maximum fine content in each subclass up to $8 \%$;

- metallurgy uses limestone consisting of five subclasses in size range from $-70+0.1 \mathrm{~mm}$.

\section{Technological scheme for the production of filler based on limestone "Gigovići”- Ulcinj}

Limestone from the deposit "Gigović" Ulcinj, because of their physical and mechanical properties (Tables 4, 5 and 6), can be used for different purposes as a technical- building stone, and for the good of the chemical composition (Tables 2 and 3), it can be used as raw material for fillers for different industries. It is therefore necessary that the technological scheme of preparation limestone "Gigović" next operation contains treatment plants that would receive different sized products for wide application in many industries.

Technological scheme has been designed in a very flexible way, so that, depending on the needs of consumers and processing capacity, production takes place in a way that each class size was obtained in a number of shifts, and then in accordance with the requirements of the market, bridging and linking technology positions receive other products of different size class.

Technological scheme of crushing and sieving is shown in Figure 6.

Exploitation of raw materials would be done by drilling and blasting of which would be received blasted stone with GGK (upper size limit) of $450 \mathrm{~mm}$. Below the primary bunker is stationary grid (pos. 3) $20 \mathrm{~mm}$ aperture, which serves to separate the waste rock in it (earth, clay and small stones faction), which is transported with conveyor belt on tailing.

Raw-sized $32 \mathrm{~mm}$ from the plant for crushing and screening goes to grinding in order to obtain milled product which is used as filler in a variety of industries that require raw and micronized limestone which "Gigovići" matched its quality. Grinding is used as the starting sieved material or can optionally be sent to the grinding classified material from any stock from S8 to S12.

The technological scheme of grinding and classification of limestone "Gigovići" is represented in Figure 7. 


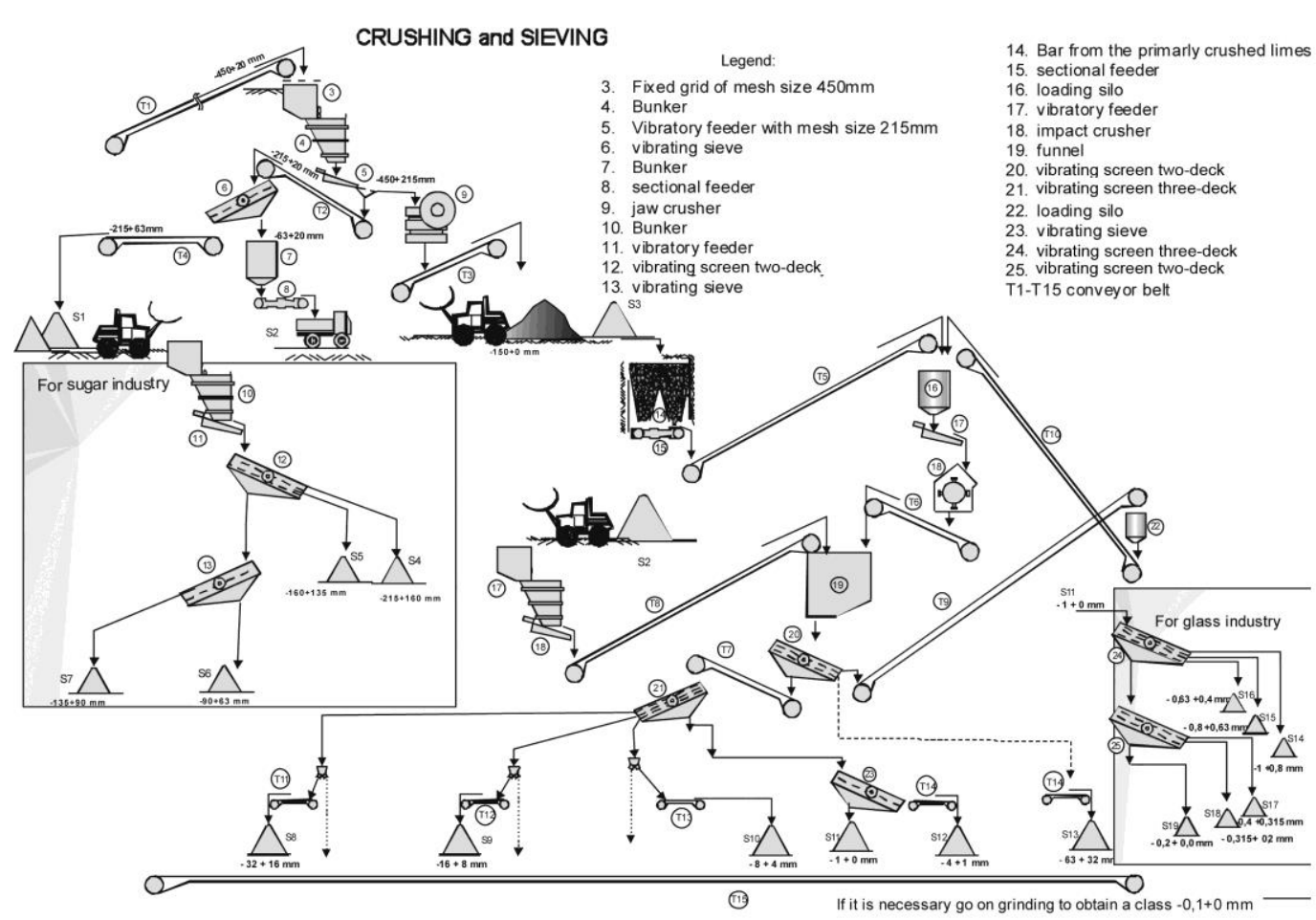

Figure 6. Technological scheme of crushing and sieving of limestone deposits "Gigovići" - Ulcinj

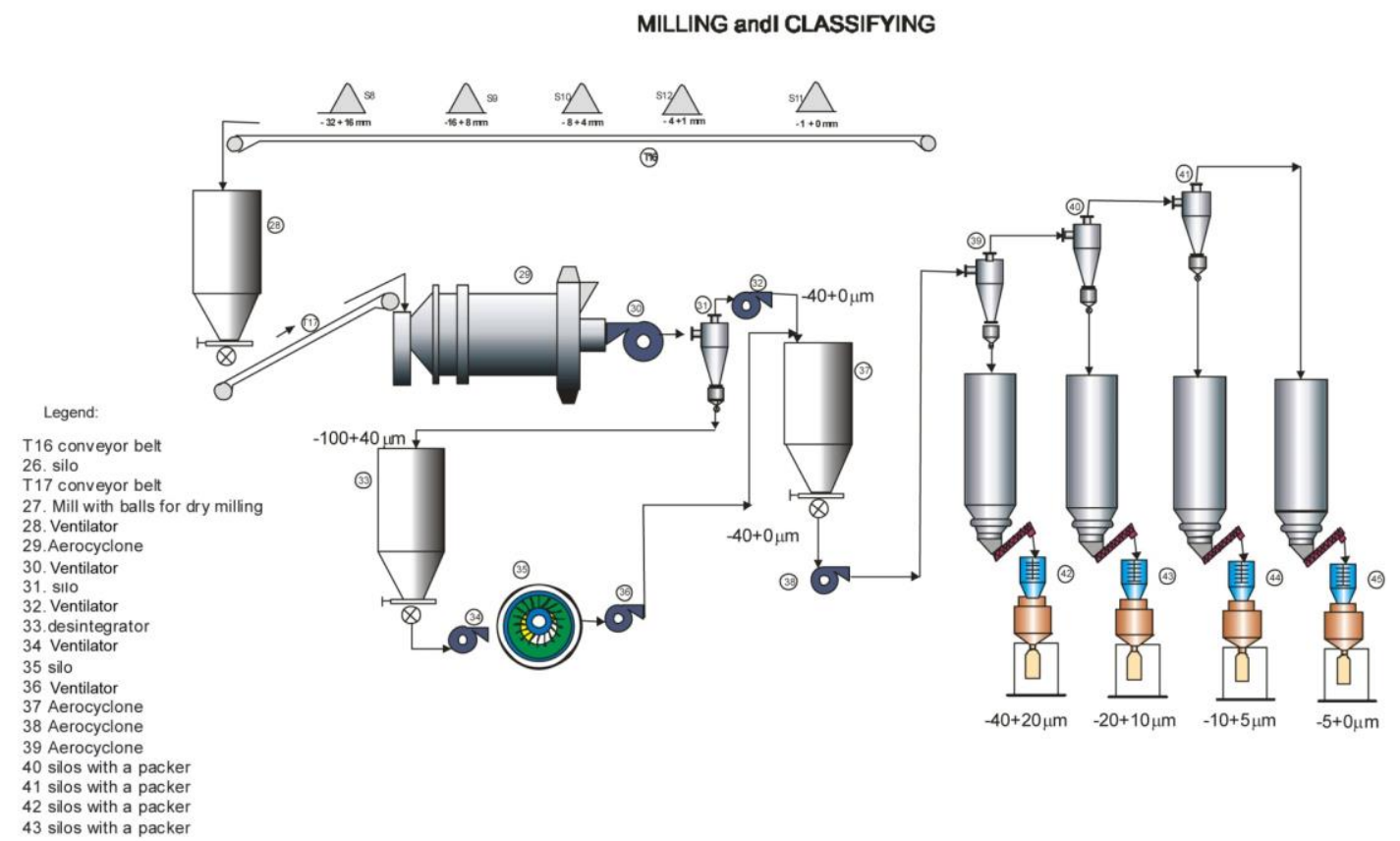

Figure 7. Technological scheme of grinding and classification of limestone deposit "Gigovići"- Ulcinj 


\section{Conclusion}

Limestone from "Gigovići"- Ulcinj deposit, according to its physico-chemical properties, belongs to high quality carbonate raw material with high $\mathrm{CaCO}_{3}$ content of $98.16 \%$, and low $\mathrm{MgCO}_{3}$ content of $1.53 \%$ and silicates $\left(\mathrm{SiO}_{2} 0.3 \%\right)$. It meets the requirements of standards for using calcium carbonates as fillers in industry of paints and coatings; paper industry, rubber and PVC industry; production of mineral fertilizers; foundry industry; sugar industry and metallurgy. According to market demand and standards, it belongs to high quality raw material in industry of paints and coatings, rubber and PVC, sugar production, foundry industry and metallurgy. However, for paper industry and production of glass, this limestone does not comply with the highest standards.

Due to the low degree of whiteness, and increased content of heavy element $(\mathrm{Pb}$ $65 \mathrm{ppm}$ ) "Gigovići" limestone cannot be used in pharmaceutical and cosmetics industry. Due to high content of biogenic elements $\mathrm{MgO}(0.73 \%), \mathrm{Fe}(340 \mathrm{ppm})$ and $\mathrm{Cu}$ (18ppm), as well as heavy metals $\mathrm{Pb}(65$ ppm), $\mathrm{Ni}(24 \mathrm{ppm})$ and $\mathrm{Cd}(9 \mathrm{ppm})$, "Gigovići" limestone cannot be used in production of cattle feed and for neutralization of acidic soils.

\section{Acknowledgments:}

This paper is a result of investigations under projects TR 31003, TR 34013 and TR 34006 , financed by the Ministry of Education and Science of the Republic of Serbia from 2011-2014.

\section{References}

[1] Gunasekaran, S., Anbalagan, G. (2008) Spectroscopic study of phase transitions in natural calcite mineral. Spectrochimica Acta Part A (69), 1246 - 1251.

[2] Radulović, D., Terzić, A., Pezo,P., Andrić,Lj., Grigorova, I. (2017) The Chemometric Study of Limestone Physico-chemical Properties and Thermal Behavior for Application in Construction Composites. Science of Sintering, 49 (3), 247-261.

[3] Dollimore, D., Dunn, J., Lee, Y., Penrod, B. (1994)The decrepitation of dolomite and limestone. Thermochimica Acta (231): 125-131. SSDZ 0040-6031 (93) 01615-A

[4] Yoğurtcuoğlu E., Uçurum,M. (2011) Surface modification of calcite by wetstirred ball milling and its properties. Powder Technology 214, 47-53.

[5] http://minerals-n-more.com/Calcite_Info.html

[6] www.minweb.co.uk/carbonates/calcite.html

[7] Saeid., D, Elnaz, S. (2016) A modified model of a single rock joint's shear behavior in limestone specimens. International Journal of Mining Science and Technology 26 (4), 577-580.

[8] Weerdt, K. D., Haha, M.B ., Saout, G.L., Kjellsen, K.O., Justnes, H., Lothenbach, B. (2011) Hydration mechanisms of ternary Portland cements containing limestone powder and fly ash. Cement and Concrete Research 41, 279-291.

[9] Felekoglu, B. (2007) Utilisation of high volumes of limestone quarry wastes in concrete industry (self-compacting concrete case). Resources, Conservation and Recycling 51 (4), 770-791.

[10] Anastasiou, E., Liapis, A., Papayianni, I. (2015) Comparative life cycle assessment of concrete road pavements using industrial by-products as alternative materials. Resources, Conservation and Recycling 101, 1-8.

[11] http://webmineral.com/data/Calcite.shtml [12] http://en.wikipedia.org/wiki/Calcite, 
[13] Yuan, P.Q., Cheng, Z.M., Zhou Z.M., Yuan, W.K., Semiat, R. (2008) Zeta potential on the anti-scalant modified sub-micro calcite surface. Colloids and Surfaces A: Physicochemical and Engineering Aspects 328 (1-3), 60-66.

[14] Radulović, D. S. (2011) The effects of ions of apatite and calcite on their surface properties, Faculty of mining and geology, Doctoral dissertation, University of Belgrade, Department of Mineral Processing, Belgrade, Serbia. ( In Serbian)

[15] Przeniosło, R., Fabrykiewicz, P., Sosnowska, I. (2016) Monoclinic deformation of calcite crystals at ambient conditions. Physica B: Condensed Matter. 496,49-56.

[16] McIntosh,R.,Sharp,J.,Wilburn,F. (1990) The thermal decomposition of dolomite. Thermochimica Acta, 165 (2), 281-296.

[17] Salvador, A.R., Calvo, E.G., Aparicio, B. (1989) Effects of sample weight, particle size, purge gas and crystalline structure on the observed kinetic parameters of calcium carbonate decomposition. Thermochimica Acta, 143, 339-345.

[18] Barcina, L.M., Espina, A., Sufirez, M., Garcia, J.R., Rodriguez, J. (1997) Characterization of monumental carbonate stones by thermal analysis (TG, DTG and DSC). Thermochimica Acta 290 (2), 181-187.

[19] William,W. D. (2011). Introduction to Mineralogy, $2^{\text {nd }} \quad$ Edition. Oxford University Press.Inc., New York.

[20] The report of the investigations of limestones from the area of Montenegro, for theirs application as a fillers in various branches of industry, ITNMS Archive, Belgrade, 2011. ( In Serbian)

[21] http://geology.com/usgs/limestone/

[22] Radulović, D.S., Petrov, M., Trumić, M.S., Trumić, M.Ž., Bogdanović, G.,
Andrić, Lj., Possibility of using limestone from „Gigovići“-Ulcinj deposit as filler in various industry branches, Proceedings of XII International Symposium on Recycling Technologies and Sustainable Development, Bor Lake, 13-15. Septembar 2017. Serbia, 97-104.

[23] Terzic, A., Radulovic, D., Pezo, L., Andric, Lj., Milicic, Lj., Stojanovic, J., Grigorova, I., (2017) The effect of mechano-chemical activation and surface treatment of limestone filler on the properties of construction composites. Composites Part B 117, 61-73.

[24] Mihajlović, S. (2011) Physico-chemical modification of calcite with stearic acid, doctoral dissertation, Faculty of Mining and Geology, Belgrade, Serbia. (In Serbian)

[25] Sekulić, Ž.T. (2011) Calcium carbonate and quartz raw materials and theirs application", Monograph, ISBN 978-8682867-24-1, ITNMS, Belgrade, 21-75. ( In Serbian)

[26] www.patentgenius.com/patent/4026762, Use of ground limestone as a filler in paper.

[27] http://minerals.usgs.gov/minerals/pubs/comm odity/stone_crushed/mcs-2010-stonc.pdf

[28] Milosavljević, R. (1974) Methods of testing mineral raw materials in the mineral processing, Faculty of Mining and Geology, Belgrade, Serbia. (In Serbian)

[29] Andersen, F., Brečević, L. (1991) Infrared Spectra of Amorphous and Crystalline Calcium Carbonate. Acta Chemica Scandinavica 45: 1018-1024.

[30] Huang, C. K., Kerr, P. F. (1960) Infrared study of the carbonate minerals. The American Mineralogist 45, 311-324.

[31] Hopkinson, L., Rutt, K., Kristova, P., Blows, J., Firth, C. (2015) Sourcing limestone masonry for restoration of historic buildings, a spectroscopic pilot 
studyJournal of Cultural Heritage 16 (6), 822-830.

[32] Vagenas,N.V., Gatsouli, A., Kontoyannis, C.G., (2003) Quantitative analysis of synthetic calcium carbonate polymorphs using FT-IR spectroscopy. Talanta 59 (4), 831-836.

[33] Ersoy-Mericboyu, A., Ktictikbayrak, S., Yavuz, R. (1993) Thermal decomposition kinetics of natural Turkish limestones under non-isothermal conditions. Thermochimica Acta, 223, 121-128.

[34] Anandakumaran, P., Bhattacharya, A. (1982) TG-DTA studies on the pyrolysis of limestone-laterite mixtures. Thermochimica Acta 59, 319-329. 